\title{
m SLINTAS
}

35.3.2019 [279-300]

\section{PENDIDIKAN DEMOKRASI,}

PERSAUDARAAN, DAN

PERSATUAN INDONESIA

DALAM TERANG DOKUMEN

\section{PERSAUDARAAN MANUSIA}

\section{(2019)}

\author{
Konstantinus Frederikus Jawa
}

\author{
| Graduate Student \\ Faculty of Philosophy \\ Parahyangan Catholic University \\ Bandung, Indonesia
}

\begin{abstract}
:
Education is meant to foster students or young people to be able to embrace life with maturity in faith, personal resilience, and sensitivity to social situations, especially changes that happen today. The spirit of national democracy in Indonesia can be realised through values education in schools so that these become material for a character building process. Values internalised in the education comprise of respect, care, acceptance, solidarity, appreciation, and sensitivity to the suffering of others. In being compassionate to the suffering others, students are called to come out of their comfort zones and to get involved with people who suffer and are in need, especially those who are victims of injustice due to the system in the society. The cultivation of human compassion can be carried on by promoting fraternity, that is, through the real encounters with people of different backgrounds, religions, races, and ethnicities. Building human fraternity in education asks that students are fostered to exercise dialogue of life and are given opportunities to encounter others in living communication. Through real encounters, education is not limited to scientific achievements, but touches affective and psychomotor aspects.
\end{abstract}

Keywords:

education • democracy • pluralism • fraternity • unity • religious dialogue • compassion 


\section{Pendahuluan}

Bangsa Indonesia adalah bangsa besar dan kaya. Indikasi kebesaran dan kekayaan tidak sekadar ditinjau dari sudut teritorial, melainkan juga dari keberagaman bangsa ini, yaitu keberagaman suku, agama, budaya, etnis, ras, bahasa, dan adat istiadat. Keberagaman ini merupakan kenyataan yang tidak dapat disangkal. Oleh karena itu, keberagaman ini bisa dipandang sebagai kekayaan bangsa. Penerimaan akan keberagaman merupakan bagian integral dari bangsa ini karena dari sinilah eksistensi bangsa Indonesia terwujud. Penerimaan keberagaman adalah peluang bagi bangsa ini menciptakan kehidupan demokrasi yang otentik demi tercapainya persatuan bangsa, yaitu persatuan yang dilandaskan pada kebaikan bersama.

Persatuan bangsa bukanlah persatuan demi keseragaman (unisitas), demi tampilan luaran, melainkan kesatuan yang didasari oleh semangat berbagi dalam keberagaman, yaitu berbagi sukacita, kesedihan, dan masalah-masalah dunia saat ini. ${ }^{1}$ Sebagai bangsa yang besar dengan kekayaan pluralnya, Indonesia memiliki peluang dalam mewujudkan kesatuan bangsa melalui semangat persaudaraan satu dengan yang lainnya. Peluang ini menjadi kesempatan bagi penegakan demokrasi yang adalah kemerdekaan dan persamaan seluruh bangsa. Kemerdekaan berarti setiap warga negara bebas berpartisipasi mewujudkan kesejahteraan manusia baik berupa sumbangan tenaga, energi, pengetahuan, maupun semangat kritis atas kinerja pemerintah yang berkuasa. Sementara itu, persamaan mengarah pada semua warga negara yang memiliki hak, kewajiban, dan martabat yang sama, karena Allah Sang Pencipta adalah Allah yang tidak membeda-bedakan. ${ }^{2}$

Dewasa ini, semangat kesatuan dalam persaudaraan antarmanusia sering dicederai oleh kepentingan pribadi atau golongan tertentu. Sebagian orang memanfaatkan keberagaman demi pencapaian pribadi maupun kelompok tertentu melalui kekuasaan. Masyarakat sering diadu domba, agama menjadi lahan kekerasan, perbedaan etnis, warna kulit, ras, budaya, dipakai untuk melanggengkan kekuasaan. Politik dipermainkan demi pemuasan kelompok tertentu sehingga mengkhianati cita-cita luhur politik, yaitu demi kepentingan dan kesejahteraan banyak orang. Politik 
dijadikan arena persaingan yang ketat dengan mengorbankan kepentingan banyak orang, bahkan mereduksi kemanusiaan manusia. Manusia yang hidup dalam keberagaman dijadikan umpan dan atau taruhan di tengah pesta demokrasi demi kepentingan pribadi atau golongan tertentu. Praktik-praktik yang tidak etis ini dilakukan hanya demi mencapai atau melanggengkan kekuasaan.

Sebagian cendekiawan, intelektual, politikus, dan golongan lain memanfaatkan perbedaan di antara manusia sebagai kesempatan melanggengkan kekuasaan dari golongannya demi kepentingan pribadi atau kelompok tertentu. Pembedaan realitas keberadaan manusia ini melahirkan polarisasi "kawan-lawan", "murni-sesat", "mayoritas-minoritas", "masuk surga-masuk neraka", dan lain-lain. Polarisasi ini menjadi akar konflik yang terjadi di Indonesia. Peristiwa-peristiwa seperti kerusuhan lima daerah di Papua ${ }^{3}$ sebagai buntut perlakuan diskriminatif dan persekusi yang dialami mahasiswa asal provinsi ini di Surabaya pada 17 Agustus 2019, ${ }^{4}$ warga negara Indonesia (WNI) yang mendukung ISIS, ${ }^{5}$ dan isu agama yang menjadi kampanye negatif di beberapa kasus pemilihan umum di Indonesia adalah contoh nyata mengentalnya polarisasi semacam ini. ${ }^{6}$ Isuisu seperti ini berlanjut dan politik identitas seakan-akan menjadi hal biasa dalam politik Indonesia. Keprihatinan lain yang sangat mendesak ialah masuknya intoleransi ke dunia pendidikan melalui buku-buku di sekolah dan SDM. ${ }^{7}$

Konflik dan permasalahan terkait pluralisme menarik perhatian banyak kalangan. Sebagian orang terjebak dalam euforia ini, tetapi tidak sedikit pula yang mengutuk tindakan-tindakan di atas. Pemerintah, pemuka agama, kaum intelektual, kaum cendekiawan, sampai masyarakat pada umumnya melakukan banyak kegiatan maupun terobosan demi meredam pergolakan dunia dewasa ini. Ketika melakukan perjalanan apostolik ke Uni Emirat Arab (UEA), Paus Fransiskus dan Imam Besar AlAzhar, Ahmad Al-Tayyeb, menandatangani Dokumen tentang Persaudaraan Manusia untuk Perdamaian Dunia dan Hidup Bersama (Document on Human Fraternity for World Peace and Living Together, disebut juga "Deklarasi Abu Dhabi", di sini disingkat Persaudaraan Manusia, 4 Februari 2019), ${ }_{8}^{8}$ sebagai usaha mewujudkan perdamaian dunia dan persaudaraan umat manusia. Pertemuan kedua pemimpin tertinggi agama ini memberi angin segar pada usaha serta kerja sama bagi dialog untuk mewujudkan perdamaian. 
Perjumpaan kedua pemimpin agama ini, menegaskan bahwa persaudaraan bukanlah semata-mata konsep, wacana, atau ide kreatif dalam pertemuan maupun imbauan, melainkan suatu dialog kehidupan yang lahir dari pengalaman perjumpaan setiap manusia. Persaudaraan adalah suatu dialog yang nyata. Oleh karena itu, perjumpaan dengan orang lain yang berbeda suku, agama, ras, dan golongan adalah suatu keniscayaan yang tidak bisa ditawar. Perjumpaan dengan mereka yang berbeda bukanlah sebuah perkara mudah, tetapi juga bukan situasi yang mustahil. Oleh karena itu, penanaman nilai persaudaraan kepada generasi muda zaman ini adalah sebuah kebutuhan mutlak dalam memperjuangkan kemanusiaan.

Penanaman nilai pada diri manusia mengenai pentingnya perjumpaan dengan manusia yang lain dapat diwadahi lewat dinamika sekolah dalam instansi pendidikan. Pendidikan merupakan lahan subur untuk mewujudkan afeksi manusia dalam persaudaraan manusia lewat perjumpaan secara langsung dengan yang lain. Situasi perjumpaan membutuhkan keberanian untuk keluar dari daerah nyaman, yaitu keberanian untuk pergi, bertemu, belajar, dan tinggal bersama orang lain. Oleh karena itu, pendidikan bukan dibatasi dalam persoalan kognitif belaka, melainkan harus diimbangi dengan spiritualitas, sikap, dan keterampilan. Para siswa tidak sekadar diarahkan pada pengembangan kognitif, melainkan didorong untuk ikut mengembangkan nilai-nilai luhur kemanusiaan yang mengarahkan pada pengalaman perjumpaan dengan situasi real masyarakat melalui dinamika pendidikan yang mengolah sisi afektif dan psikomotoriknya.

\section{Persaudaraan Manusia dalam Dokumen Persaudaraan Manusia}

Dokumen Persaudaraan Manusia yang ditandatangani Paus Fransiskus dan Imam Besar Ahmad Al-Tayyeb pada 2019 ini berusaha melihat keterkaitan manusia yang satu dengan manusia yang lain. Keterkaitan ini dilandasi oleh iman kepada Allah yang telah menciptakan semua manusia setara dalam hak, kewajiban, dan martabat, serta memanggil semua manusia untuk hidup bersama sebagai saudara, memenuhi bumi dan menyebarkan nilai-nilai kebaikan, cinta, dan kedamaian. ${ }^{9}$ Perjumpaan kedua tokoh internasional ini menghasilkan misi persaudaraan bagi dunia, yaitu membangun persaudaraan di tengah dunia, khususnya dengan mengembangkan kepekaan pada situasi dunia, kepekaan pada kemiskinan struktural, anak yatim, janda, pengungsi, dan mereka yang diasingkan, atas 
nama orang-orang yang kehilangan keamanan, kedamaian, keterpisahan akibat bencana dan perang, politik ekstremisme dan perpecahan, tindakan diskriminasi, dan ketidakadilan lainnya di dunia ini. ${ }^{10}$

Kepekaan pada situasi dunia dapat diwujudkan lewat membangun persaudaraan manusia, yaitu persaudaraan yang dilandasi oleh bela-rasa (compassion). Sikap semacam ini memanggil setiap manusia untuk peka pada penderitaan orang lain, untuk mencoba menyelami penderitaan orang yang miskin dan mereka yang menjadi korban tindakan yang tidak manusiawi. Bela-rasa bukan sekadar ungkapan belas kasihan (simpati), melainkan sebuah upaya untuk ikut merasakan penderitaan orang lain dengan ikut ambil bagian menjadi agen persaudaraan. Membangun persaudaraan manusia bukanlah sebuah perkara mudah, melainkan sebuah proses panjang yang mesti ditanamkan secara terus-menerus dalam diri manusia dengan membangun sikap bela rasa dalam penderitaan, bencana, dan malapetaka. Selain itu, juga diperlukan upaya menumbuhkan keyakinan bahwa di antara penyebab paling utama dari krisis dunia modern adalah hati nurani manusia yang kehilangan kepekaaan dan yang menjauhkan diri dari nilai-nilai agama, dan adanya individualisme yang dominan, berikut filosofi materialistis yang mendewakan pribadi manusia sehingga mereduksi prinsip-prinsip paling tinggi dan transendental. ${ }^{11}$

Krisis dunia modern dalam dokumen Persandaraan Manusia tersebut bukanlah sebuah situasi yang harus ditangisi dan disesali tanpa harapan, melainkan sebuah pesan inspiratif bagi dunia untuk bergandengan tangan membangun dunia lewat persaudaraan manusia. Persaudaraan manusia tidak dilakukan sekadar dengan pengakuan verbal akan eksistensi manusia yang lain, melainkan bergerak bersama membangun dunia lewat kepekaan akan situasi dunia, khususnya krisis dunia modern saat ini, termasuk di Indonesia. Membangun kepekaan akan situasi sulit dunia membutuhkan proses panjang dan melibatkan daya kreatif semua orang dan lembaga.

Oleh karena itu, wadah penting yang dapat digunakan dalam proyek besar dan panjang ini adalah dunia pendidikan. Pendidikan dapat dimaknai sebagai sebuah proses pembelajaran untuk terjadinya perubahan dan pertumbuhan dalam upaya mencerdaskan kehidupan bangsa. ${ }^{12}$ Di dalam dokumen tersebut dikatakan bahwa pendidikan merupakan wadah yang paling strategis dalam mewujudkan persaudaraan di tengah masyarakat yang tidak sekadar mengetahui, melainkan tergerak hati dan budinya untuk

\section{3}


mengusahakan segala sesuatu yang baik, benar, dan indah. Melalui dunia pendidikan, persaudaraan manusia dapat menjadi sebuah agenda bersama dalam mendidik generasi baru untuk membawa kebaikan serta kedamaian bagi orang lain, dan di mana-mana menjadi pembela hak-hak mereka yang lemah dan tertindas. ${ }^{13}$

\section{Realitas Pendidikan di Indonesia}

Polemik yang terjadi dalam dunia pendidikan maupun dalam realitas bangsa Indonesia saat ini tidak dapat dipisahkan dari perjalanan panjang pendidikan bangsa ini. Karakter bangsa Indonesia saat ini merupakan warisan turun temurun kebijakan pendampingan karakter melalui pendidikan. Perjalanan panjang pendidikan di Indonesia dibumbui kebijakan yang rumit dan terus-menerus mengalami perubahan. Pada zaman penjajahan, yakni penjajahan Belanda dan Jepang, pendidikan yang diterapkan di Indonesia adalah pendidikan demi kepentingan pemerintah kolonial. Pendidikan bangsa ini pernah mengarah pada pendidikan yang membodohkan masyarakat, sebab penerapannya justru menjadikan bangsa ini jauh dari kecerdasan, sikap kritis, dan kepekaan terhadap setiap situasi sekitar. $^{14}$

Pasca kemerdekaan, pendidikan diupayakan dapat membawa karakter bangsa kepada kebaikan. Setelah masa kemerdekaan, bangsa Indonesia memulai era baru dalam roda pemerintahan. Sukarno didaulat memimpin bangsa Indonesia dalam masa pemerintahan Orde Lama. Pada masa itu, dunia pendidikan diberi ruang kebebasan. Konsep pemerintahan Sukarno yang berasaskan sosialisme memberi peran pada dunia pendidikan dalam pembangunan dan diarahkan untuk pembentukan masa depan bangsa Indonesia. ${ }^{15}$ Sukarno pada dasarnya menggarisbawahi pendidikan sebagai hak semua masyarakat tanpa memandang kelas sosial apapun. Dengan kata lain, paham ini memberikan kesempatan kepada semua bangsa Indonesia untuk mengenyam pendidikan. Semua warga negara Indonesia tanpa memandang perbedaan suku, agama, ras, maupun golongan berhak mendapatkan pendidikan. ${ }^{16}$ Pada masa ini, dunia pendidikan diberi angin segar oleh pemerintah. Ribuan mahasiswa disekolahkan ke luar negeri, mahasiswa disebar ke pelosok negeri untuk mengatasi buta huruf, dan guru-guru pun diperbantukan di negara-negara tetangga 
untuk meningkatkan kualitas pendidikan mereka. Pada masa ini, jumlah mahasiswa di universitas-universitas melonjak, upah bagi tenaga pengajar menjadi perhatian pemerintah, dan dunia akademik mendapatkan kebebasannya sebagai sebuah mimbar intelektual. ${ }^{17}$

Sistem demokrasi pada masa Orde Lama menjadi sangat terbuka, mengangkat kesamaan hak dan kewajiban antarsesama warga negara, termasuk dalam bidang pendidikan menjadi agenda utama pada masa pemerintahan presiden pertama Indonesia ini. Sistem sosialisme yang diusung Orde Lama memberikan kesempatan bagi bangsa Indonesia untuk memperjuangkan hak dan martabatnya, yaitu kesejahteraan. Wadah yang digunakan menuju orientasi itu adalah dunia pendidikan. Pendidikan diyakini mampu melepaskan bangsa ini dari kebodohan dan penindasan, juga dari kepanikan karena inferioritas bangsa sebagai bangsa terjajah. Pendidikan di masa ini menjadi model pendidikan yang diyakini memberi peluang untuk keluar dari zona kebodohan dan kemiskinan.

Pada masa pemerintahan Orde Lama, pendidikan merupakan prioritas karena setiap warga negara diberi kesempatan untuk mengembangkan dirinya dengan kewajiban mengenyam dunia pendidikan. Pada masa ini pula, tenaga-tenaga pengajar dibentuk sebagai "pahlawan tanpa tanda jasa" yang dihormati dan dilabeli nasionalis. Menjadi pendidik atau guru adalah menjadi sosok yang mencintai bangsa dan negara. Pada masa ini, para guru, penilik (pengawas), dan perangkat di dalam institusi pendidikan memandang siswa sebagai peserta didik, sehingga para pendidik bertanggung jawab atas pertumbuhan dan perkembangan peserta didik. Pada masa kelaparan atau krisis, para pendidik pun bisa memperlakukan peserta didik layaknya anak-anak mereka sendiri, melalui perhatian dan bimbingan yang intens. ${ }^{18}$ Komunitas pendidikan pada masa Orde Lama tidak bertahan dalam keadaan yang sama. Saat Suharto menjadi presiden dan memulai masa Orde Baru, sistem pendidikan mengalami perubahan.

Di masa Orde Baru, dunia pendidikan mengalami degradasi. Siswa tidak lagi diperlakukan sebagai peserta didik, melainkan sebagai objek dari segala lapisan mulai dari negara, sistem, sekolah, guru, dan pasar. Para siswa hanya dilihat berdasarkan angka dengan nilai kelulusan dan tidak lulus UN (Ujian Nasional). ${ }^{19}$ Pada masa ini, Orde Baru memandang kemajemukan atau pluralitas bangsa Indonesia sebagai ancaman bagi kestabilan politik sehingga keberagaman harus dikendalikan, diseragamkan, atau bahkan

\section{5}


ditundukkan menurut cita rasa kekuasaan. ${ }^{20}$ Kejatuhan kepemimpinan Orde Baru pada 1998 diharapkan mampu menciptakan kesejahteraan yang adil serta kebebasan seluruh rakyat Indonesia, tapi ternyata hal itu masih jauh dari harapan.

Pada waktu itu, demokrasi di Indonesia cenderung menjadi bias dengan kepentingan golongan tertentu, sehingga timbullah konflik atas nama perbedaan. Kemajemukan atau perbedaan etnis, agama, warna kulit, golongan, suku, budaya, ras, manusia yang satu dengan yang lain dipakai sebagai senjata oleh oknum tertentu demi kepentingannya sendiri atau kelompoknya. Bahkan, pada masa itu demokrasi yang berasaskan perwakilan atau demokrasi Pancasila hanya menjadi instrumen pemusatan kekuasaan, sehingga demokrasi pun menjadi sekadar jargon. Demokrasi periode ini melahirkan kekacauan politik yang memunculkan protes yang memuncak pada Mei 1998. ${ }^{21}$ Kekacauan politik ini pada akhirnya melahirkan periode selanjutnya, yaitu Masa Reformasi.

Orde Baru tampaknya merupakan masa kesuksesan menerapkan sistem yang hendak menjaga stabilitas politik seturut kehendak penguasa. Suharto dengan Orde Barunya menjadi semakin otoritarian. Jejak kepemimpinannya diingat oleh banyak kalangan. Salah satu kebijakan khas Orde Baru mempertahankan kekuasaannya ialah melalui pendekatan ideologis yang dirumuskan dalam berbagai macam aspek kehidupan masyarakat, seperti pendidikan, kebudayaan, sosial-ekonomi, dan politik. ${ }^{22}$ Dalam dunia pendidikan, pemerintahan Orde Baru menerapkan beberapa kurikulum, yaitu kurikulum 1968, 1975, 1984, dan 1994. Kurikulum 1968 dikategorikan sebagai kurikulum yang paling dipengaruhi gejolak politik karena sebagian besar perencanaan pembelajaran difokuskan pada penghapusan jejak pendidikan pada masa pemerintahan Presiden Sukarno (Orde Lama). Sementara itu, tiga kurikulum lain diarahkan untuk mendapatkan luaran yang seragam dari peserta didik. Mereka diharapkan dapat menjadi tenaga yang terampil, berbudi luhur, dan berpedoman kepada agama serta nilai-nilai Pancasila.

Pada masa itu, kurikulum lebih bersifat sentralistik karena pemerintahan Suharto cenderung memaksakan gagasan dari pusat ke daerah. Kebijakankebijakan yang dibuat oleh pemerintah pusat harus diterapkan di seluruh pelosok Indonesia tanpa memperhatikan perbedaan-perbadaan orang dengan latar belakang daerah, adat-istiadat, kebiasaan, pola pikir, dan lain- 
lain. Pendidikan di masa Orde Baru sarat dengan indoktrinasi, karena tujuannya adalah untuk menanamkan ideologi Pancasila di seluruh jenjang pendidikan. ${ }^{23}$ Selain itu, indoktrinasi ini berlanjut pada kurikulum 1984 melalui mata pelajaran Pendidikan Sejarah dan Perjuangan Bangsa (PSPB). Ide dasar penerapan kurikulum ini ialah bahwa peserta didik dituntut untuk menghafal kisah-kisah pahlawan nasional yang didominasi oleh orang-orang dari angkatan bersenjata. Usaha pemerintahan Orde Baru melanggengkan kekuasaannya lewat dunia pendidikan kental dengan sistem pendidikan yang kaku dan tertutup, karena erat kaitannya dengan pendiktean dari atas ke bawah, yaitu dari pemerintahan pusat kepada dunia pendidikan di seluruh pelosok tanah air. Hal ini merupakan strategi penguasa untuk tetap memimpin negara dengan membodohkan masyarakat dengan pendidikan yang berbasis kepentingan politik praktis.

Usaha Orde Baru ini dapat menjadi bahan evaluasi bagi masyarakat Indonesia kini yang tengah bergejolak dengan kemajemukan. Dunia pendidikan dapat menjadi wadah utama dan penting dalam mewujudkan persaudaraan manusia di Indonesia di tengah perbedaan yang adalah keniscayaan bangsa. Pendidikan tidak lagi dilihat secara kaku dan tertutup, melainkan lebih terbuka dan dinamis, dan yang bergerak bersama perkembangan teknologi dan sumber daya manusia bangsa ini.

Runtuhnya kekuasaan Orde Baru pada 1998 menjadi gerbang perwujudan demokrasi di Indonesia. Sebagian besar kalangan menyakini negara Indonesia akan memasuki era baru, yaitu kesejahteraan dan kedamaian. Pada masa ini, bangsa Indonesia hidup dalam sistem demokrasi, tetapi demokrasi yang berjalan dalam dinamika bangsa ini adalah demokrasi yang didominasi oleh kebebasan yang tidak terbatas, sehingga pertikaian manusia yang satu dengan yang lainnya semakin marak di tengah masyarakat. ${ }^{24}$ Realitas ini diperburuk lagi dengan kemajuan teknologi dan informatika. Masyarakat diporak-porandakan dengan beritaberita yang bertebaran di media sosial maupun media cetak. Setiap orang dapat mengakses maupun 'menciptakan' apapun yang dikehendakinya tanpa berorientasi pada kebenaran.

Perubahan dari Orde Baru menuju Reformasi mempengaruhi segala aspek kehidupan bangsa Indonesia, dan tanpa terkecuali dunia pendidikan. Kebijakan yang berkaitan dengan dunia pendidikan selalu mengarah pada sesuatu yang bersifat reformatif dan revolusioner. ${ }^{25}$ Pembaruan kebijakan 
pendidikan ditandai dengan disahkannya Undang-Undang No. 22 Tahun 1999 tentang pemerintahan daerah, yang diperkuat oleh Undang-Undang No. 25 Tahun 1999, yang menegaskan bawa kebijakan pendidikan tidak lagi ditentukan dari pemerintahan pusat, melainkan diberikan wewenang kepada ranah lokal, yaitu kepada pemerintah daerah (kabupaten maupun lokal). ${ }^{26}$

Pada masa reformasi, upaya mencerdaskan kehidupan bangsa dilakukan dengan mewujudkan perluasan dan pemerataan kesempatan bangsa Indonesia untuk memperoleh pendidikan yang bermutu tinggi demi terwujudnya manusia Indonesia yang berkualitas. Harapan akan terwujudnya bangsa Indonesia yang memiliki pendidikan yang bermutu tinggi sejalan dengan terwujudnya keadilan dan kesejahteraan bagi seluruh rakyat Indonesia. Akan tetapi, dalam realitasnya, perjalanan demokrasi di Indonesia didominasi oleh kebebasan yang tidak terbatas yang ditandai dominasi kaum penguasa, politik uang, kepentingan kelompok, kepentingan pribadi, serta premanisme. ${ }^{27}$ Bahkan, pada masa ini ada penguasa (dunia politik) berusaha dengan segala cara untuk mempertahankan kekuasaan atau dominasi mereka dengan 'mempermainkan' semboyan keberagaman negara, yaitu "Bhinneka Tunggal Ika". Semboyan negara yang berasal dari realitas bangsa Indonesia yang lahir dari keberagaman, dipermainkan demi kelanggengan kekuasaan. Perbedaan agama, etnis, ras, dan perbedaan lainnya dijadikan senjata untuk menyerang kelompok yang tidak seiyasepikir. Kasus-kasus intoleransi atas nama agama, tindakan diskriminasi atas perbedaan warna kulit, dan tindakan tidak manusiawi lainnya mewarnai perjalanan demokrasi bangsa Indonesia.

Oleh karena itu, pendidikan kini menjadi ranah paling strategis untuk mewujudkan semangat persaudaraan di antara manusia yang terlahir dalam keberagaman. Persaudaraan bukanlah semata-mata wacana atau usaha yang ada pada ranah teoretis maupun konseptual, melainkan sebuah usaha perjumpaan yang di dalamnya meliputi dialog, yaitu sapaan dan komunikasi yang konkret. Dalam perjumpaan, setiap orang dipanggil untuk mewujudkan persaudaraan yang komunikatif, yaitu persaudaraan yang dilandaskan pada tindakan bela-rasa (compassion). Tindakan bela-rasa atau kompasi merupakan kepekaan pada situasi manusia lain, terutama mereka yang miskin dan menderita. Kepekaan ini tidak sekadar terletak pada ranah simpati, melainkan meliputi keterlibatan untuk mendukung 
(dengan moralitas, materi, pendampingan, perhatian) terhadap semua orang yang menderita. Kepekaan pada manusia lain dilandaskan pada semangat menerobos perbedaan dari dalam kemajemukan yang sering menjadi alasan perwujudan persaudaraan dan persatuan Indonesia.

\section{Pendidikan Demokrasi: Wadah Perwujudan Persaudaraan Manusia}

Membangun persaudaraan sejati berhubungan langsung dengan membangun demokrasi yang otentik. Inti demokrasi adalah kemerdekaan dan persamaan, dan orientasi keduanya adalah persaudaraan. ${ }^{28}$ Persaudaraan adalah sebuah nilai universal bagi setiap manusia yang memiliki ikatan biologis, psikologis, spiritual, maupun kemanusiaan. Melalui persaudaraan ini, sekat sosial, jabatan, ekonomi, suku, agama, ras, maupun golongan dapat diminimalisasi. Nilai persaudaraan antarmanusia seperti ini mampu menciptakan kesatuan. Kesatuan di sini adalah kesatuan yang mantap dan bertahan, yang dilandasi oleh minat atau kesadaran pribadi. Persatuan yang langgeng ini dapat terwujud lewat persahabatan dan kasih sayang, yaitu lewat persaudaraan. Oleh karena itu, usaha untuk mewujudkan persatuan dimulai dengan menggalang persaudaraan. ${ }^{29}$ Menggalang persaudaraan harus sampai pada perjumpaan dengan cara 'berbagi', yaitu berbagi sukacita, kesedihan, dan masalah-masalah dunia, dengan tidak mengabaikan budaya yang lain, dan dengan saling menghargai. ${ }^{30}$

Dalam Kristianitas, khususnya melalui Injil Markus, Yesus Kristus mengatakan, "Barangsiapa melakukan kehendak Allah, dialah saudaraKu laki-laki, dialah saudara-Ku perempuan, dialah ibu-Ku” (Mrk. 3:35). Ungkapan Yesus ini menegaskan bahwa persaudaraan manusia adalah milik dan tanggung jawab semua manusia, karena Allah menghendaki demikian. Melakukan kehendak Allah berarti mengasihi Allah dengan segenap hati dan jiwa serta mengasihi sesama manusia (Luk. 10:27). Berdasarkan pemahaman ini, semua manusia pada dasarnya dikasihi Allah. Oleh karena itu, setiap manusia bertanggung jawab mewujudkan perdamaian dengan menjadikan persaudaraan sebagai model hidup bersama dalam mewujudkan kebaikan bersama.

Persatuan dalam keberagaman yang dapat diwujudkan lewat persaudaraan manusia tampaknya sulit diwujudkan dalam relasi kehidupan 
manusia. Berkembangnya paham ekstremisme, terorisme, diskriminasi, kesenjangan sosial, politik identitas, dan perang saudara menunjukkan bahwa nilai persaudaraan itu masih jauh dari harapan. Akhir-akhir ini dunia dihebohkan dengan berbagai pergolakan dan permasalahan kemanusiaan. Perang saudara, perang antarnegara, perang agama, perjuangan kemanusiaan baik ekonomi maupun sosial, menjadi konsumsi masyarakat melalui media cetak, daring, dan visual. Manusia bersaing dengan manusia lain, dengan negara, agama, ideologi, dan organisasi lain. Persaingan ini sering adalah demi menunjukan kedigdayaan diri maupun kelompok tertentu, sehingga segala cara dilakukan, termasuk tindakan kekerasan. Umumnya persaingan diorientasikan pada pembuktian diri sebagai sosok atau kelompok yang 'paling': paling kuat, pintar, perkasa, maju, dan benar. Persaingan dan pembuktian diri inilah yang pada akhirnya melahirkan polarisasi dalam kehidupan manusia: 'kawan atau lawan', 'murni atau sesat', 'mayoritas atau minoritas', 'kelompok teman atau kelompok lawan', 'benar atau salah', 'tinggi atau rendah', ${ }^{31}$ dan lain-lain.

Oleh karena itu, perwujudan persaudaraan adalah usaha mendesak yang mesti diwujudkan atau ditanamkan dalam diri generasi muda kini. Persaudaraan adalah sebuah dialog yang nyata, maka perjumpaan dengan orang lain yang berbeda suku, agama, ras, dan golongan adalah keniscayaan tanpa tawar-menawar. Penanaman nilai pada manusia tentang pentingnya perjumpaan dengan manusia yang lain dapat diwadahi dalam dinamika di sekolah dan instansi pendidikan. Pendidikan adalah lahan subur untuk mewujudkan sisi afektif manusia dalam perwujudan persaudaran manusia lewat perjumpaan secara langsung dengan yang lain. Situasi perjumpaan menuntut keberanian untuk keluar dari daerah nyaman.

Pendidikan demokrasi dalam hal ini dapat menjadi alternatif untuk mewujudkan persaudaraan manusia. Pendidikan demokrasi merupakan suatu kesempatan penanaman nilai-nilai secara bertahap dan sistematis kepada peserta didik sehingga nilai-nilai itu dapat menyatu dalam perilakunya. Oleh karena itu, dalam proses pembelajaran perlu dicari berbagai model, pendekatan, dan strategi yang sesuai dengan kondisi lingkungan dan sosial budaya masyarakat setempat. ${ }^{32}$ 


\section{Metode Pembelajaran Multikultur}

Mengingat realitas konflik dan permasalahan demokrasi bangsa ini, pendidikan mesti ikut ambil bagian dalam perwujudan dan pembentukan pandangan kaum muda mengenai kehidupan serta penghargaan terhadap keberagaman, dengan tidak meninggalkan identitas atau keunikan diri. Metode pembelajaran multikultur dapat diintegrasikan pertama-tama lewat kurikulum yang digunakan. Model kurikulum multikultur bisa mencakup dua hal, yatu bidden curriculum (kurikulum yang tidak tertulis dan terencana, namun memuat proses internalisasi nilai, pengetahuan, dan keterampilan dalam dinamika pendidikan) dan academic curriculum (kurikulum yang diterapkan dalam perencanaan yang tertulis dan digunakan dalam sistem pendidikan).

Dalam model kurikulum multikultur, peserta didik didorong untuk mengintegrasikan proses pembelajaran nilai, pengetahuan, dan keterampilan hidup dalam masyarakat yang multikultur. Ketiga arah pembelajaran ini dapat didesain sesuai dengan tahap perkembangan peserta didik dan jenjang pendidikan. Dalam proses pembelajaran nilai, dinamika pendidikan mesti memuat isi multikultural yang mendorong terjadinya internalisasi nilai-nilai. Dalam tahap perolehan pengetahuan proses dapat dimulai dari pengenalan, penghormatan, dan penghargaan terhadap diri sendiri, termasuk keluarga dan institusi yang membantu membentuk peserta didik. Proses pengenalan dan penghormatan, serta penghargaan terhadap diri sendiri diperluas hingga meliputi pengenalan, penghormatan, dan penghargaan terhadap orang lain. Hal ini dapat diwujudkan dengan pengenalan atau pengetahuan tentang berbagai suku, etnis, adat, tradisi, agama, bahasa daerah yang ada di salah satu daerah di Indonesia. Proses terakhir adalah proses keterampilan. Dalam proses pembelajaran ini peserta didik didorong untuk bernegosiasi, membangun jaringan dengan orang lain, mengemukakan dan menghadapi perbedaan. ${ }^{33}$ Praksis mewujudkan atau menginternalisasi nilai ini dapat diberikan lewat kesempatan bagi peserta didik untuk berani mengambil keputusan (discerment).

Model kurikulum multikultur ini sifatnya berangkat dari diri sendiri, yaitu menghormati dan menghargai diri sendiri, dan bergerak menuju pengetahuan untuk menghargai dan menghormati orang lain. Hal itu bisa dilakukan dengan wawasan kebangsaan, yaitu pengetahuan akan keberagaman bangsa dan semboyan negara, seperti Bhinneka Tunggal 
Ika, serta dengan pemberian kesempatan memperoleh pengetahuan atau pendidikan kewarganegaraan dengan hak dan kewajiban, demokrasi, dan hak asasi manusia. Pada aspek nilai, setiap peserta didik didorong untuk memiliki kepekaan pada situasi di luar dirinya, seperti empati kemanusiaan, moral dan budi pekerti, serta kasih sayang terhadap sesama manusia. Sementara itu, aspek keterampilan dapat memuat cooperative learning, penyelesaian masalah, komunikasi, dan resolusi konflik. ${ }^{34}$

\section{Pendidikan Karakter}

Pendidikan karakter dalam dunia pendidikan merupakan kebutuhan aktual. Sebagian besar masyarakat memandangnya sebagai salah satu unsur penting dalam dunia pendidikan. Hal ini muncul sebagai reaksi terhadap kecenderungan yang menghalalkan segala cara demi kepentingan pribadi maupun kelompok dengan mengorbankan nilai-nilai kebaikan termasuk mereduksi harapan setiap individu. Gejala ini pulalah yang mendorong banyak kalangan termasuk pemerintah Indonesia untuk menetapkan implementasi pendidikan karakter sejak 2011. Penetapan ini bukanlah yang terakhir, melainkan berlanjut dengan penegasan pentingnya pendidikan karakter dalam dunia pendidikan lewat Perpres No. 87 (2017) tentang penguatan pendidikan karakter.

Karakter adalah pola perilaku yang bersifat individual mengenai keadaan moral seseorang. Dengan kata lain, karakter berkaitan dengan suatu kualitas moral dan perilaku pribadi seseorang yang membedakan dirinya dengan orang lain. ${ }^{35}$ Pemahaman ini sejalan dengan tujuan pendidikan nasional, yaitu mengembangkan potensi peserta didik agar menjadi manusia yang beriman dan bertakwa kepada Tuhan yang Maha Esa, berakhlak mulia, sehat, berilmu, cakap, kreatif, mandiri, dan menjadi warga negara yang demokratis dan bertanggung jawab. ${ }^{36}$ Pendidikan karakter adalah bagian penting dalam membangun bangsa yang religius, nasionalis, mandiri, berintegritas, dan mampu bergotong royong. ${ }^{37}$ Dalam perwujudannya, semangat-semangat ini adalah penting sehingga setiap tindakan atau dinamika kelas di dalam dunia pendidikan mesti berorientasi pada pendidikan karakter.

Pelaksanaan pendidikan karakter kepada peserta didik, khususnya generasi muda, membutuhkan proses pembiasaan. Pelaksanaan ini membutuhkan waktu yang lama, berkesinambungan, terpadu, dan komprehensif. Pendidikan karakter mesti memadukan unsur kurikulum 
tidak tertulis dan kurikulum akademik. Dalam kurikulum tidak tertulis, unsur terpenting dalam dunia pendidikan adalah keteladanan para pendidik, relasi peserta didik dan pendidik, staf sekolah, dan dengan peserta didik yang lain, relasi antarpendidik dan staf sekolah, suasana keberagaman, proses pembelajaran, penilaian pembelajaran, pengolahan lingkungan sekolah, dan kebijakan disiplin. Sementara itu, kurikulum akademik lebih berkaitan dengan mata pelajaran dan program-program ko-kurikuler, serta kegiatan ekstrakulikuler yang ada di sekolah. ${ }^{38}$

Kedua unsur tersebut merupakan bagian penting dalam perwujudan pendidikan karakter kepada peserta didik. Ada kalanya pelaksanaan pendidikan lebih terpusat pada kurikulum akademik sehingga cenderung menomorduakan kurikulum tidak tertulis. Pada dasarnya kedua bagian tersebut tidak dapat dipisahkan. Pendidikan karakter berorientasi pada potensi, keteladanan, dan proses pembinaan, dan dengan demikian sekolah memiliki peran penting dalam menumbuhkembangkan karakter peserta didik. Tujuan pendidikan karakter adalah menanamkan nilai-nilai dan mengembangkan sikap serta perilaku yang baik untuk membentuk karakter. Ini membutuhkan peran serta berbagai kalangan, baik keluarga, gereja sebagai lembaga keagamaan, lembaga pendidikan itu sendiri, pemerintah, masyarakat pada umumnya, dan interaksi di antara peserta didik.

\section{Pendidikan Dialogis}

Pendidikan dialogis adalah konsep pendidikan yang mempertegas peran pendidik dan peserta didik. Posisi kedua subjek dalam dunia pendidikan ini mesti setara. Artinya, dalam dinamika proses pembelajaran, pendidik tidak lebih tinggi daripada peserta didik, melainkan keduanya berada dalam situasi atau proses yang sama, yakni proses pembelajaran. Dalam proses pembelajaran, pendidik atau guru bukanlah satu-satunya sumber pengetahuan. Oleh karena itu, pemberian kesempatan kepada peserta didik untuk menemukan materi pembelajaran lewat wadah yang lain sangat dibutuhkan, misalnya melalui internet, diskusi kelompok, maupun sarana observasi lain yang membuka dialog.

Pendidik merupakan subjek yang berpengaruh dalam dunia pendidikan, maka pendidik mesti mampu menyentuh hati peserta didik agar apa yang disampaikan dalam kelas mampu diserap dengan baik oleh peserta didik.

\section{3}


Dalam kurikulum 2013, pendidik tidak dipandang sekadar sebagai pengajar yang mentransfer ilmu, melainkan sebagai pendamping bagi peserta didik. Dalam hal ini, peserta didik adalah subjek proses pembelajaran. Oleh karena itu, pendidik harus mampu menampilkan metode pengajaran yang membangkitkan inisiatif dan kreativitas peserta didik. Dalam proses pembelajaran, pendidikan dialogis mendorong pendidik dan peserta didik saling menyerap ilmu, termasuk dari pengalaman pribadi masing-masing. Dengan kata lain, pendidik dan peserta didik saling belajar satu sama lain, termasuk dari pengalaman dan pengetahuan yang dimiliki.

\section{Pendidikan Perjumpaan}

Pendidikan bukanlah sekadar mentransfer ilmu dari pendidik kepada peserta didik, melainkan juga berkaitan dengan proses menemukan dan mengeksplorasi pengalaman hidup. Ada yang mengatakan bahwa pengalaman merupakan pendidikan yang pertama dan utama karena melalui pengalaman seluruh bagian hidup manusia ditumbuhkan dan dikembangkan. Kardinal Bergoglio yang kemudian menjadi Paus Fransiskus pernah mengatakan bahwa "sekolah-sekolah merupakan tempat khusus untuk perjumpaan antara sesama manusia dan juga merupakan tempat khusus untuk mendapatkan pengalaman yang berorientasi pada perjumpaan, solidaritas, dan pembentukan komunitas." ${ }^{39}$ Ungkapan ini memberikan penegasan bahwa dinamika sekolah bukanlah sekadar urusan ilmiah, melainkan berkaitan dengan berbagai macam pendekatan, salah satunya ialah lewat proses pembelajaran yang konkret, yaitu perjumpaan dengan orang lain, khususnya mereka yang miskin dan menderita. Beberapa metode yang mendukung konsep pendidikan perjumpaan dijelaskan sebagai berikut.
Live-In
Dalam usaha perwujudan pendidikan demokrasi, yaitu pendidikan yang berorientasi pada tindakan menghargai, solider, dan sikap kompasi kepada orang lain termasuk mereka yang berbeda, metode pendidikan live-in dipandang efektif dalam mendukung pendidikan demokrasi bangsa. Metode live-in memberi kesempatan kepada peserta didik untuk mengalami dan merasakan cara hidup atau realitas hidup orang lain, khususnya mereka yang berbeda latar belakang. 
Pada metode pendidikan ini, peserta didik diberi kesempatan untuk keluar dari zona nyamannya masing-masing, yakni dengan pergi ke tempat mereka dapat berjumpa atau bertemu dengan orang lain yang berbeda latar belakang, baik ekonomi, agama, budaya, suku, maupun ras. Dalam perjumpaan itu, peserta didik mendapat kesempatan untuk belajar mengenai banyak hal, seperti belajar untuk menghargai hidup, bersyukur atas apa yang dimiliki dan sedang dijalani, belajar untuk peka pada realitas sosial, dan suatu ketika mereka akan mampu tinggal ${ }^{40}$ bersama orang baru dan bahkan yang belum mereka kenal, untuk merasakan keadaan yang tidak enak atau belum pernah dialami. Kelanjutan metode ini ialah suatu saat mereka siap meninggalkan tempat live-in dengan cara pandang baru tentang kehidupan, serta memiliki semangat baru untuk menghargai, bersikap solider, peka, toleran, kompasi, dan untuk membangun persaudaraan di manapun dan kapanpun serta kepada siapapun, tanpa membedakan latar belakang setiap orang yang dijumpai.

\section{Visitasi Perbedaan}

Pendidikan demokrasi berorientasi pada kesejahteraan, perdamaian, keadilan, dan kemakmuran seluruh umat manusia. Akan tetapi, harapan ini sering dicederai oleh oknum tertentu yang menggunakan agama untuk mengutuk perbedaan, sehingga sering terjadi konflik atas dasar agama. Dalam Toward a Mankind School: An Adventure in Humanistic Education, John Goodlad menegaskan bahwa ajaran agama apapun pasti mengajarkan atau berbicara tentang kebaikan. ${ }^{41}$ Dengan kata lain, otentisitas setiap agama maupun aliran kepercayaan terletak pada nilai-nilai kebaikan. Setiap agama bersumber dari kebaikan dan berorientasi pada kebaikan pula. Dalam semangat ini, perwujudan demokrasi di dunia pendidikan di Indonesia mesti menanamkan sikap toleransi kepada mereka yang berbeda agama. Salah satu metode untuk menanamkan semangat toleransi dan persaudaraan pada peserta didik ialah dengan mengadakan program "kunjungan rohani" yaitu mengunjungi berbagai rumah ibadat, seperti gereja, mesjid, vihara, kelenteng, dan pura. Dalam kunjungan itu, peserta didik diberi kesempatan untuk bertanya dan mendalami pengetahuan lewat interaksi langsung dengan orang-orang yang berbeda agama. Dengan 
demikian, peserta didik diberi pengetahuan juga, terutama lewat pengalaman untuk menghargai dan membangun sikap toleran dalam keberagaman. Dengan metode ini, peserta didik juga mengenal dan memahami bahwa perbedaan bukanlah halangan untuk mewujudkan kesejahteraan, perdamaian, keadilan, dan kemakmuran.

\section{Simpulan}

Indonesia sebagai negara yang besar dengan keberagamannya menghadapi tantangan-tantangan dalam tindakan-tindakan intoleran, diskriminasi, situasi politik dan keprihatinan lain yang memacu bangsa ini untuk terus berbenah diri. Banyak kebijakan dicanangkan demi terwujudnya bangsa yang aman, adil, dan makmur. Perubahan kebijakan dan sistem pemerintahan merupakan strategi bangsa ini lewat pemerintahnya, untuk menjawab tantangan zaman yang terus-menerus berubah dengan cepat. Pembaruan sistem demokrasi di Indonesia merupakan salah satu alternatif bangsa ini untuk keluar dari berbagai permasalahan sosial.

Membangun demokrasi sejalan dengan membangun persaudaraan di antara umat manusia. Inti demokrasi adalah kemerdekaan dan persamaan, dan muara keduanya adalah persaudaraan. Oleh karena itu, untuk mewujudkan kemerdekaan dan persamaan di antara manusia, mesti diperjuangkan persaudaraan sejati dalam interaksi bangsa ini. Membangun kesadaran persaudaraan bukanlah sebuah tindakan mudah, tetapi juga bukan tindakan yang mustahil untuk diwujudkan. Pendidikan demokrasi dapat menjadi salah satu cara dalam perwujudan persaudaraan manusia, yaitu persaudaraan yang dilandasi oleh iman, kasih, dan harapan. Berlandaskan iman, karena keyakinan bahwa Allah menciptakan semua manusia tanpa diskriminasi. Kasih, karena Allah pun menciptakan manusia dengan kasih yang besar, sehingga Ia menghendaki manusia membagikan kasih yang sama kepada sesamanya. Harapan, sebab selalu ada harapan demi kebahagiaan dan perdamaian jika kesadaran pada persaudaraan menjadi bagian dari kehidupan semua manusia.

Dalam usaha perwujudan ini, pendidikan mesti melibatkan semua pihak. Pendidikan demokrasi dalam hal ini berorientasi pada penanaman nilai-nilai secara bertahap dan sistematis pada peserta didik, sehingga apa yang ditanamkan menjadi karakter diri. Perwujudan demokrasi merupakan 
keniscayaan dalam kehidupan masyarakat Indonesia yang sangat beragam. Demokrasi sarat dengan nilai-nilai luhur yang dapat mengantar manusia kepada kesejahteraan, perdamaian, keadilan, persaudaraan, kesatuan (unitas), dan kemakmuran. Demokrasi ini mesti dilaksanakan secara konsisten dan konsekuen dalam kehidupan politik dan dalam kehidupan bermasyarakat, berbangsa, serta bernegara. Melalui pendidikan demokrasi, masyarakat, khususnya generasi muda, diberi pemahaman tentang demokrasi yang benar sehingga berusaha memperjuangkan nilai-nilai demokrasi di dalam kehidupan mereka sehari-hari.

\section{Referensi:}

Bergoglio, Jorge. Embusan Harapan bagi Dunia yang Tertindas. Yogyakarta: Fidei Press, 2015.

Cadore, Bruno. "Dialogue as a Hope of Truth", dalam Thiery-Marie Courau \& Carlos Mendoza-Alvarez, Diverse Cultural and Religious Ways of Thinking: A Dialogue. London, SCM Press, 2017.

Darmaningtyas. Pendidikan yang Memiskinkan. Yogyakarta: Galang Press, 2004.

Deklarasi tentang Pendidikan Kristen (Gravissimum Educationis). Jakarta:

Komisi Pendidikan KWI, 2008.

Djalil, Matori. "Dari Harmoni Semu ke Persaudaraan Sejati”, dalam A. Widyahadi Seputra (Ed.), Menggalang Persatuan Indonesia Baru: Sudut Pandang Tokoh Masyarakat Pemuka Agama dan Kepercayaan. Jakarta: Komisi PSE/APP-Keuskupan Agung Jakarta, 2000.

Dokumen tentang Persaudaraan Manusia untuk Perdamaian Dunia dan Hidup Bersama. Judul asli: Document on Human Fraternity for World Peace and Living Together. Terj. Martin Harun, OFM. Jakarta: Obor, 2019.

Gaffar, Mohammad. Dinamika Pendidikan Nasional: Isu, Tantangan, dan Perspektif Masa Depan. Bandung: UPI Press, 2012.

Goodlad, John \& Hirschfeld, Gerhard. "Education for Mankind", dalam John I. Goodlad, Toward A Mankind School: An Adventure In Humanistic Education. New York: McGraw-Hill, 1974. 
Kasper, Walter. That They May All Be One: The Call To Unity Today. London: The Tower Building, 2004.

Kementerian Pendidikan dan Kebudayaan. Model Penilaian Karakter. Jakarta: Pusat Penilaian Pendidikan, 2019.

Lie, Anita. Pendidikan: Antara Kebijakan dan Praksis. Surabaya: Widya Mandala Press, 2015.

Sugiharto, Bambang. "Agama dan Paradigma Abad XXI", dalam

Bartolomeus Samho, et. al., Agama dan Kesadaran Kontemporer. Yogyakarta: Kanisius, 2019.

Magnis-Suseno, Franz. "Menggalang Persaudaraan: Juga dengan Saudara-

Saudara Muslim?”, dalam A. Widyahadi Seputra (Ed.), Menggalang

Persatuan Indonesia Baru: Sudut Pandang Tokoh Masyarakat Pemuka Agama dan Kepercayaan. Jakarta: Komisi PSE/APP-Keuskupan Agung Jakarta, 2000.

Susetyo, Benny. Politik Pendidikan Penguasa. Yogyakarta: LKiS, 2005.

Yamin, Moh. Menggugat Pendidikan Indonesia: Belajar dari Paulo Freire dan Ki Hajar Dewantara. Yogyakarta: Ar-Ruzz Media, 2009.

\section{Endnotes:}

1 Lih. Dokumen Tentang Persaudaraan Manusia untuk Perdamaian Dunia dan Hidup Bersama (Document on Human Fraternity for World Peace and Living Together, disebut juga "Deklarasi Abu Dhabi", 4 Februari 2019), terj. Martin Harun OFM (Jakarta: Obor, 2019) 3; selanjutnya disingkat Persaudaraan Manusia.

2 Bdk. ibid., 5.

3 Kota Jayapura, Kabupaten Deiyai, Kota Timika, Wamena (Kabupaten Jayawijaya) dan Oksibil (Kabupaten Pegunungan Bintang).

4 Antara/M. Risyal Hidayat, "94 Tersangka Kerusuhan Papua" Tempo (20 Oktober 2019) 24, dan "Papua Mencekam” Tempo (8 September 2019) 18.

5 Islamic State of Iraq and Syria adalah organisasi gerilyawan Islam Irak dan Suriah yang bertujuan membangun negara Islam Sunni (kekhalifahan) yang dipimpin oleh pemerintahan keagamaan di bawah pimpinan agung Khalifah yang diyakini sebagai pengganti Nabi Muhammad.

6 "Selamat Tinggal Politik Identitas" Tempo, 28 Maret 2016.

7 Survei Wabid Institute melaporkan pada 2016 ada 60\% aktivis agama di sekolah yang bersedia melakukan 'jihad' ke Suriah, 10\% menyatakan bahwa serangan teroris di jalan M.H. Thamrin, Jakarta, pada awal 2016 adalah perbuatan 'jihad', dan 6\% mendukung kelompok Negara Islam Irak dan Suriah (ISIS). Sementara itu, survei Pusat Pengkajian Islam dan Masyarakat, Universitas Islam Negeri Syarif Hidayatullah, Jakarta, melaporkan bahwa 5,95\% guru memiliki opini radikal secara 
eksplisit, 2,58\% secara implisit, 4,56\% guru bersedia melakukan aksi intoleran, dan $33,21 \%$ guru bersedia melakukan tindakan intoleran (survei terhadap 2.237 guru Muslim pada 2018), serta 48,95\% responden berpendapat bahwa pendidikan agama mempengaruhi mereka agar tidak bergaul dengan pemeluk agama lain, sedangkan $58,5 \%$ responden memiliki pandangan keagamaan radikal (survei terhadap 1.522 siswa, 337 mahasiswa, dan 264 guru di 34 provinsi pada 2017). Selain dua survei di atas, Setara Institute juga melaporkan hasil survei 3\% siswa tidak bersedia berteman dengan yang berbeda agama, 4,5\% siswa menganggap orang yang berbeda cara beribadahnya adalah kafir, $0,7 \%$ tidak akan menolong teman yang berbeda agama ketika tertimpa musibah, satu siswa mendukung terorisme, tiga siswa membiarkan terorisme, lima siswa mendukung ISIS, dan 85 siswa mendukung tegaknya khilafah di Indonesia (survei di 171 sekolah menengah atas di DKI Jakarta dan Bandung pada 2016). Lih. "Paham Khilafah Di Sekolah" Tempo, 24 November 2019, 20.

8 Lih. Persaudaraan Manusia.

9 Ibid., Art. 4.

10 Bdk. ibid., Art. 5-10.

11 Ibid., Art. 17.

12 Mohammad Fakry Gaffar, Dinamika Pendidikan Nasional, Isu, Tantangan, dan Perspektif Masa Depan (Bandung: UPI Press, 2012) 14.

13 Persaudaraan Manusia, Art. 39.

14 Moh. Yamin, Menggugat Pendidikan Indonesia: Belajar dari Paulo Freire dan Ki Hajar Dewantara (Yogyakarta: Ar-Ruzz Media, 2009) 81.

15 Bdk. ibid., 87.

16 Bdk. Deklarasi tentang Pendidikan Kristen Gravissimum Educationis (Jakarta: Komisi Pendidikan KWI, 2008) Art. 1.

17 Moh. Yamin, op., cit., 88-89.

18 Anita Lie, Pendidikan: Antara Kebijakan dan Praksis, (Surabaya: Universitas Widya Mandala Press, 2015) 10.

19 Ibid., 11.

20 Matori Abdul Djalil, "Dari Harmoni Semu ke Persaudaraan Sejati", dalam A. Widyahadi Seputra (Ed.), Menggalang Persatuan Indonesia Baru: Sudut Pandang Tokoh Masyarakat Pemuka Agama dan Kepercayaan (Jakarta: Komisi PSE/APP-Keuskupan Agung Jakarta, 2000) 136.

21 Fakry Gaffar, op. cit., 255.

22 Abdul Djalil, art. cit., 137.

23 Darmaningtyas, Pendidikan yang Memiskinkan (Yogyakarta: Galang Press, 2004) 70.

24 Bdk. Fakry Gaffar., op. cit., 137.

25 Benny Susetyo, Politik Pendidikan Penguasa (Yogyakarta: LKiS, 2005) 2.

26 UU No. 22 Tahun 1999, Pasal 11.

27 Fakry Gaffar, op. cit., 255.

28 Abdul Djalil, "Dari Harmoni Semu ke Persaudaraan Sejati”, art. cit., 141.

29 Franz Magnis-Suseno, "Menggalang Persaudaraan: Juga Dengan Saudara-Saudara Muslim?", dalam A. Widyahadi Seputra (Ed.), Menggalang Persatuan Indonesia Baru: Sudut Pandang Tokoh Masyarakat Pemuka Agama dan Kepercayaan (Jakarta: Komisi PSE/APP-Keuskupan Agung Jakarta, 2000) 49. 
30 Bdk. Walter Kasper, That They May All Be One: The Call to Unity Today (London: The Tower Building, 2004) 17.

31 Bdk. Bambang Sugiharto, "Agama dan Paradigma Abad XXI", dalam Bartolomeus Samho, et. al., Agama dan Kesadaran Kontemporer (Yogyakarta: Kanisius, 2019) 11 dan 19.

32 Fakry Gaffar, op. cit., 253.

33 Anita Lie, op., cit., 8.

34 Bdk. ibid., 9.

35 Kementerian Pendidikan dan Kebudayaan, Model Penilaian Karakter (Jakarta: Pusat Penilaian Pendidikan, 2019) 5.

36 Ibid., 1.

37 Ibid.

38 Ibid., 1-2

39 Card. Jorge Mario Bergoglio, Embusan Harapan bagi Dunia yang Tertindas, terj. Clarindo Publication (Yogyakarta: Fidei Press, 2015) Art. 13 dan 14.

40 Bdk. Bruno Cadorè OP, "Dialogue as a Hope of Truth", dalam Thiery-Marie Courau \& Carlos Mendoza-Alvarez, Diverse Cultural and Religious Ways of Thinking: A Dialogue. London (SCM Press, 2017) 112.

41 John I. Goodlad dan Gerhard Hirschfeld, "Education for Mankind", dalam John I. Goodlad, Toward A Mankind School: An Adventure In Humanistic Education (New York: McGraw-Hill, 1974) 1-2. 